\title{
Exploring the Binding Sites of Anti-Infliximab Antibodies in Pediatric Patients With Rheumatic Diseases Treated With Infliximab
}

\author{
MIHA KOSMAČ, TADEJ AVČIN, NATAŠA TOPLAK, GABRIELE SIMONINI, ROLANDO CIMAZ, \\ AND VLADKA ČURIN ŠERBEC
}

\begin{abstract}
Department for Production of Diagnostic Reagents and Research [M.K., V.Č.Š.], Blood Transfusion Centre of Slovenia, University of Ljubljana, SI-1000 Ljubljana, Slovenia; Department of Allergology, Rheumatology and Clinical Immunology [T.A., N.T.], University Children's Hospital, University Medical Centre, SI-1000 Ljubljana, Slovenia; Department of Paediatrics [G.S., R.C.], Anna Meyer Children's Hospital, University of Florence, 50139 Florence, Italy
\end{abstract}

\begin{abstract}
Over the past decade, the treatment of a variety of immune-mediated diseases has improved greatly due to the introduction of biologics for therapies in cases that are nonresponsive to traditional treatments. However, a side effect not encountered in traditional treatments is the immunogenicity of the biologics themselves. Our aim was to investigate the anti-infliximab-antibody response in pediatric patients receiving infliximab for juvenile idiopathic arthritis and other pediatric rheumatic diseases, with a focus on an analysis of the binding sites of these antibodies. We show that anti-infliximab antibodies developed in $43 \%$ of patients receiving infliximab therapy. Neutralization studies showed that in all these patients, the antibodies were directed toward the variable domains of infliximab, as they inhibited binding of infliximab to TNF. A more precise determination of the antibody epitopes using synthetic peptides was not achieved, indicating that all the antibody binding sites were composed of discontinuous segments of infliximab. (Pediatr
\end{abstract} Res 69: 243-248, 2011)

$\mathbf{J}^{\mathrm{u}}$ uvenile idiopathic arthritis (JIA) is the umbrella term for a heterogeneous group of inflammatory arthropathies that can affect children and young adults. As the name suggests, the cause and pathogenesis of JIA are still largely unknown but are thought to include both genetic and environmental factors. Although none of the drugs available for treatment of JIA provides a cure, disease prognosis has improved greatly in recent years due to improved disease management and with the introduction of biologics that can provide an efficient alternative for patients who are nonresponsive to other treatments (1). Infliximab is one such biological agent, which acts by blocking the activity of TNF in the inflammatory response. Although infliximab is not formally approved for use in JIA, it is commonly used and its efficacy has been documented in several studies (2-5).

Infliximab is a chimeric MAb composed of variable domains of murine origin and constant domains of human origin $(6,7)$. Although it is usually well tolerated and safe for JIA therapy (8), an important aspect for consideration is its im-

Received May 10, 2010; accepted October 8, 2010

Correspondence: Miha Kosmač, Department for Production of Diagnostic Reagents and Research, Blood Transfusion Centre of Slovenia, Šlajmerjeva 6, SI-1000 Ljubljana, Slovenia; e-mail: miha.kosmac@ztm.si

Supported by the Slovenian Research Agency. munogenicity. It has become clear in recent years that all biologics have some degree of immunogenicity, even fully humanized ones. This can lead to the development of so-called antidrug antibodies (9), which can lead to loss of efficacy of treatment and higher incidence of adverse events (10).

The generation and specificity of anti-infliximab antibodies has not been well studied in pediatric patients. Therefore, in this study, we analyzed the levels of infliximab and antiinfliximab antibodies in patients with JIA and other pediatric rheumatic diseases, from two European pediatric centers. We also looked for possible epitopes of these antibodies, using overlapping synthetic peptides that covered the amino acid sequences of both of the infliximab variable domains.

\section{METHODS}

Patients and sera. Twenty-one pediatric patients receiving infliximab for treatment of rheumatic diseases were included in this study. The patients were from two European pediatric rheumatology centers (University Children's Hospital, Ljubljana, Slovenia, and Anna Meyer Children's Hospital, Florence, Italy). The study was approved by the Slovenian National Medical Ethics Committee, and oral and written consent for study participation were obtained from the patients or the legal guardians of the patients. Infliximab was administered i.v. at a dose of $3-5 \mathrm{mg} / \mathrm{kg}$ at wk 0,2 , and 6 and then at 4 - to 8 -wk intervals. The concomitant immunomodulatory medications were methotrexate in 19 patients, leflunomide in one patient, and cyclosporine A in one patient. In all cases, sera were collected immediately before the next infusion of infliximab. Sera were also collected from 50 healthy blood donors for negative controls.

Infliximab. Infliximab (Schering Plough Central East AG, Luzern, Switzerland) was obtained in powdered form and diluted to $10 \mathrm{mg} / \mathrm{mL}$ in saline solution. To obtain the infliximab Fab fragment, infliximab was digested with immobilized papain (Pierce, Rockford, IL), according to the manufacturer instructions, and the Fab fragment was purified using HiTrap rProtein A FF A columns (GE Healthcare, Uppsala, Sweden). Both infliximab and the infliximab Fab fragment were biotinylated using the Sulfo-NHS-LCl-Biotin reagent (Pierce), according to the manufacturer instructions.

Immunoassays. ELISA experiments were performed by immobilizing the required antigen overnight at $4^{\circ} \mathrm{C}$ in ELISA microplate wells (High Binding, Corning Costar, NY) in carbonate/bicarbonate buffer, $\mathrm{pH}$ 9.6. Recombinant human TNF (recHuTNF; PeproTech EC, Ltd., London, UK) was immobilized at $0.3 \mu \mathrm{g} / \mathrm{mL}$, and infliximab or the infliximab Fab fragment was diluted to 2 $\mu \mathrm{g} / \mathrm{mL}$, unless otherwise specified. The wells were then washed three times

Abbreviations: 2D-PAGE, two-dimensional polyacrylamide gel electrophoresis; HRP, horseradish peroxidase; IEF, isoelectric focusing; JIA, juvenile idiopathic arthritis; recHuTNF, recombinant human TNF; RT, room temperature 
with microplate-washing buffer $(10 \mathrm{mM}$ sodium phosphate, $150 \mathrm{mM} \mathrm{NaCl}$, $0.05 \%$ Tween-20, and $\mathrm{pH} 7.2$ ) and blocked with blocking buffer (1\% BSA in microplate washing buffer) for $1 \mathrm{~h}$ at $37^{\circ} \mathrm{C}$. Before addition to the wells, all samples and reagents were diluted as required in blocking buffer and incubated in the wells for $1.5 \mathrm{~h}$ at $37^{\circ} \mathrm{C}$. Binding was visualized by adding $50 \mu \mathrm{L}$ 3,3',5,5'-tetramethylbenzidine substrate (Calbiochem, La Jolla, CA) to the washed wells for $20 \mathrm{~min}$ at $37^{\circ} \mathrm{C}$, and the reactions were stopped by adding $50 \mu \mathrm{L} 2 \mathrm{M} \mathrm{H}_{2} \mathrm{SO}_{4}$.

Membrane-based immunoassay experiments were performed by applying the antigen in a spot directly on the nitrocellulose membrane (Protran, Whatman $\mathrm{GmbH}$, Dassel, Germany) for $1 \mathrm{~h}$ at room temperature (RT). The membranes were then blocked with 5\% skimmed milk in membrane-washing buffer (Tris-buffered saline, $0.1 \%$ Tween-20) overnight at $4^{\circ} \mathrm{C}$. All samples and reagents were diluted as required in $1 \%$ skimmed milk in membranewashing buffer and allowed to bind for $1.5 \mathrm{~h}$ at RT. The binding was visualized using Amersham ECL Western blotting detection reagents and analysis system (GE Healthcare).

Serum testing. The serum trough infliximab concentrations were measured using indirect ELISA by immobilizing recHuTNF. The serum concentration of infliximab was determined by adding serum samples to immobilized recHuTNF and detecting the bound infliximab with a horse radish peroxidase (HRP)-conjugated goat anti-human $\operatorname{IgG}$ (Fc-specific) polyclonal antibody (Sigma Chemical Co. Aldrich, St. Luis, MO). Known concentrations of infliximab were prepared and incubated in parallel with serum samples. Fifty serum samples from infliximab-naïve donors were tested in parallel to determine assay specificity and cutoff for infliximab positivity.

Anti-infliximab antibody levels were assayed using a one-step, doubleantigen bridging ELISA, essentially as described by Bourdage et al. (11). To microplate-immobilized infliximab, $25 \mu \mathrm{L}$ of either biotinylated infliximab or biotinylated $\mathrm{Fab}$ infliximab (both at $0.07 \mu \mathrm{g} / \mathrm{mL}$ in blocking buffer) were added, followed immediately by $25 \mu \mathrm{L}$ serially diluted serum samples. These were incubated for $3 \mathrm{~h}$ at $37^{\circ} \mathrm{C}$. Known concentrations of affinity-purified anti-infliximab antibodies were serially diluted in blocking buffer and incubated in parallel with the serum samples. HRP-conjugated avidin (Pierce) was used to detect the bound complexes. The values were converted into equivalence units per milliliter $(\mathrm{EqU} / \mathrm{mL})$, which were equivalent to nanogram per milliliter of the reference serum. Fifty serum samples from infliximab-naïve donors were also tested to determine assay specificity and cutoff for antiinfliximab antibody positivity.

The ability of sera from anti-infliximab-antibody-positive patients to inhibit binding of infliximab to TNF was tested by competition ELISA. RecHuTNF was immobilized to microplate wells. Biotinylated infliximab Fab fragment $(90 \mathrm{ng} / \mathrm{mL})$ was incubated separately with serial dilutions of sera. The complexes were then incubated with the microplate-immobilized recHuTNF. HRP-conjugated avidin was used to detect the bound complexes. Fifty serum samples from infliximab naïve donors were also tested to determine assay specificity. The serum dilution that still exceeded 50\% inhibition, compared with the signal obtained in the absence of serum, was taken as the neutralizing titer.
Affinity purification of anti-infliximab antibodies. Infliximab $(10 \mathrm{mg} / \mathrm{mL}$ in saline solution) was immobilized on cyanogen-bromide-activated agarose beads using the AminoLink Plus Coupling Resin (Pierce), according to the manufacturer instructions. Anti-infliximab antibodies from sera of patients that tested positive for high titers of these antibodies were purified according to the manufacturer instructions. The fractions were collected and tested for anti-infliximab antibody positivity using the one-step, double-antigenbridging ELISA test described earlier. Positive fractions were pooled and concentrated using Amicon Ultra-4 centrifuge filter units (Millipore Corporation, Billerica, MA).

Two-dimensional PAGE (2D-PAGE) of anti-infliximab antibodies. Approximately $20 \mu \mathrm{g}$ affinity-purified anti-infliximab antibodies from a patient with a high concentration of anti-infliximab antibodies was analyzed by 2D-PAGE. The samples were subjected to isoelectric focusing (IEF) using an Ettan IPGphor II IEF system (GE Healthcare) and 24-cm, nonlinear, pH 3-11 Immobiline DryStrips (GE Healthcare), according to the manufacturer instructions. The IEF conditions included rehydration loading of the immobilized $\mathrm{pH}$ gradient strips for $12 \mathrm{~h}, 50 \mathrm{~V}$ for $2 \mathrm{~h}, 200 \mathrm{~V}$ for $1 \mathrm{~h}, 500 \mathrm{~V}$ for $1 \mathrm{~h}$, $1000 \mathrm{~V}$ (gradient) for $1 \mathrm{~h}, 8000 \mathrm{~V}$ (gradient) for $3 \mathrm{~h}$, and $8000 \mathrm{~V}$ for $4 \mathrm{~h}$.

After IEF, the strips were equilibrated with equilibration buffer $(50 \mathrm{mM}$ Tris-HCl, pH 8.8, $6 \mathrm{M}$ urea, 30\% glycerol, and 2\% SDS), followed by reduction and alkylation in equilibration buffer supplemented with $0.5 \%$ DTT and $1.25 \%$ iodoacetamide. The strips were loaded onto $12 \%$ polyacrylamide gels, and the second dimension was run using an Ettan DALTsix electrophoresis system (GE Healthcare) at $2 \mathrm{~W} /$ gel for $45 \mathrm{~min}$, followed by $17 \mathrm{~W} / \mathrm{gel}$ until adequate separation was obtained. After separation, the gels were fixed and silver stained, as described by Mortz et al. (12).

IgG subtype determination of anti-infliximab antibodies. The IgG subtypes of anti-infliximab antibodies were determined using the PeliClass IgG subclass ELISA kit (Sanquin Reagents, Amsterdam, The Netherlands), according to the manufacturer instructions.

Epitope mapping. A set of 56 overlapping 15-mer peptides that encompassed the variable domain amino acid sequences of both the heavy and the light chain of infliximab (7), along with two additional random 15-mer peptides for negative controls, were synthesized commercially by Peptide 2.0 (Miami, FL). The peptides were 15 amino acid residues in length, with sequential peptides overlapping by 11 residues (Table 1 ). These peptides were dissolved in $50 \%$ acetonitrile to $\sim 10 \mathrm{mg} / \mathrm{mL}$ and stored at $-80^{\circ} \mathrm{C}$ until use. The exact concentrations were measured using BCA Protein Assay Reagent (Pierce), with modifications as described by Kapoor et al. (13) for measurement of peptide concentrations.

In experiments using membrane-immobilized peptides, the peptides were immobilized as spots on a nitrocellulose membrane at $\sim 5 \mu \mathrm{g}$ per spot. Ten nanograms of infliximab Fab fragment was also spotted as positive control. Binding of anti-infliximab antibodies to the immobilized peptides was assayed by incubating the membranes with the various sera diluted from 1/100 to $1 / 500$ and detecting bound antibodies using a HRP-conjugated goat antihuman $\operatorname{IgG}$ (Fc-specific) polyclonal antibody.

Table 1. Synthetic overlapping peptides used for epitope mapping

\begin{tabular}{rlllll}
\hline No. & Amino acid sequence & No. & Amino acid sequence & No. & Amino acid sequence \\
\hline 1 & EVKLEESGGGLVQPG & 21 & VYLQMTDLRTEDTGV & 41 & RLLIKYASESMSGIP \\
2 & EESGGGLVQPGGSMK & 22 & MTDLRTEDTGVYYCS & 42 & KYASESMSGIPSRFS \\
3 & GGLVQPGGSMKLSCV & 23 & RTEDTGVYYCSRNYY & 43 & ESMSGIPSRFSGSGS \\
4 & QPGGSMKLSCVASGF & 24 & TGVYYCSRNYYGSTY & 44 & GIPSRFSGSGSGTDF \\
5 & SMKLSCVASGFIFSN & 25 & YCSRNYYGSTYDYWG & 45 & RFSGSGSGTDFTLSI \\
6 & SCVASGFIFSNHWMN & 26 & NYYGSTYDYWGQGTT & 46 & SGSGTDFTLSINTVE \\
7 & SGFIFSNHWMNWVRQ & 27 & STYDYWGQGTTLTVS & 47 & TDFTLSINTVESEDI \\
8 & FSNHWMNWVRQSPEK & 28 & YWGQGTTLTVSSAST & 48 & LSINTVESEDIADYY \\
9 & WMNWVRQSPEKGLEW & 29 & GTTLTVSSASTKGPS & 49 & TVESEDIADYYCQQS \\
10 & VRQSPEKGLEWVAEI & 30 & DILLTQSPAILSVSP & 50 & EDIADYYCQQSHSWP \\
11 & PEKGLEWVAEIRSKS & 31 & TQSPAILSVSPGERV & 51 & DYYCQQSHSWPFTFG \\
12 & LEWVAEIRSKSINSA & 32 & AILSVSPGERVSFSC & 52 & QQSHSWPFTFGSGTN \\
13 & AEIRSKSINSATHYA & 33 & VSPGERVSFSCRASQ & 53 & SWPFTFGSGTNLEVK \\
14 & SKSINSATHYAESVK & 34 & ERVSFSCRASQFVGS & 54 & TFGSGTNLEVKRTVA \\
15 & NSATHYAESVKGRFT & 35 & FSCRASQFVGSSIHW & 55 & GTNLEVKRTVAAPSV \\
16 & HYAESVKGRFTISRD & 36 & ASQFVGSSIHWYQQR & 56 & EVKRTVAAPSVFIFP \\
17 & SVKGRFTISRDDSKS & 37 & VGSSIHWYQQRTNGS & 57 & MRFGAKEGWTLDESA* \\
18 & RFTISRDDSKSAVYL & 38 & IHWYQQRTNGSPRLL & 58 & ECGEITNEQVSLRSR* \\
19 & SRDDSKSAVYLQMTD & 39 & QQRTNGSPRLLIKYA & & \\
20 & SKSAVYLQMTDLRTE & 40 & NGSPRLLIKYASESM & & \\
\hline
\end{tabular}

\footnotetext{
* Negative control peptides.
} 
In experiments using indirect ELISA, the peptides were immobilized in ELISA microplate wells at $1 \mu \mathrm{g} / \mathrm{mL}$. Ten nanograms of infliximab was also immobilized as positive control. Binding of anti-infliximab antibodies to the immobilized peptides was assayed by incubating the membranes with the various sera diluted 1/500 and detecting the bound antibodies using a HRPconjugated goat anti-human $\mathrm{IgG}(\mathrm{Fc}$-specific) polyclonal antibody

In experiments using competitive ELISA, the synthesized peptides were mixed in equivalent amounts for $120 \mu \mathrm{g} / \mathrm{mL}$ of each peptide and used to inhibit binding of anti-infliximab antibodies to infliximab in solution. Infliximab was immobilized in ELISA microplate wells, and anti-infliximabpositive sera were diluted in blocking buffer, for a final ELISA signal without inhibition of $\sim 0.5-1.0$. Serial dilutions of the mixed peptides were added to the various sera, and these were added to biotinylated infliximab and incubated with the immobilized infliximab for $3 \mathrm{~h}$ at $37^{\circ} \mathrm{C}$. HRP-conjugated avidin was used to detect the bound complexes.

Immunodetection of membrane-immobilized infliximab Fab fragment.

Serial 2-fold dilutions of infliximab Fab fragment (1.0, 0.5, 0.25, 0.125, $0.0625,0.03125,0.015625$, and $0.0078125 \mathrm{mg} / \mathrm{mL}$ ) were prepared either in PBS or in PBS supplemented with 2\% SDS and 5\% 2-mercaptoethanol (heated to $95^{\circ} \mathrm{C}$ for 5 min to completely denature the Fab fragment). One microliter spots were immobilized on nitrocellulose membranes for $1 \mathrm{~h}$ at RT The membranes were then incubated with affinity-purified anti-infliximab antibodies diluted to $5 \mu \mathrm{g} / \mathrm{mL}$, and the binding was detected using a HRPconjugated goat anti-human $\mathrm{IgG}(\mathrm{Fc}$-specific) polyclonal antibody.

\section{RESULTS}

Patients. A total of 111 serum samples were tested from 21 patients with rheumatic diseases from two European pediatric centers. The number of sera samples tested per individual patients ranged from 1 to 20 (mean $\pm \mathrm{SD}, 4.7 \pm 3.1$ ). The baseline demographic and clinical characteristics of the patients are summarized in Table 2. Two patients developed infusion-related reactions during or within $1 \mathrm{~h}$ after completion of infliximab infusion. The first was a 7-y-old boy with systemic JIA who developed urticarial rash, severe angioedema, and difficulty breathing after 24 mo of successful therapy with infliximab. The second was a 4 -y-old girl with systemic JIA who experienced an acute allergic reaction with chills, fever, and diffuse pain after the third infliximab infusion. No patient in the study had a delayed-type hypersensitivity reaction.

Table 2. Baseline demographic and clinical characteristics of the patients $(N=21)$

\begin{tabular}{lc}
\hline \multicolumn{1}{c}{ Characteristics } & Number of patients $(\%)^{*}$ \\
\hline Female gender & $13(62)$ \\
Mean age, range (y) & $11(4-18)$ \\
Rheumatic disease & \\
Juvenile idiopathic arthritis & $18(86)$ \\
Systemic arthritis & $6(29)$ \\
Extended oligoarthritis & $4(19)$ \\
Polyarthritis & $3(14)$ \\
Enthesitis-related arthritis & $2(10)$ \\
Psoriatic arthritis & $2(10)$ \\
Persistent oligoarthritis + uveitis & $1(5)$ \\
Behçet's disease & $1(5)$ \\
Sarcoidosis & $1(5)$ \\
Idiopathic uveitis & $1(5)$ \\
Concomitant immunosuppressive medication & \\
Methotrexate & $19(90)$ \\
Leflunomide & $1(5)$ \\
Cyclosporine A & $1(5)$ \\
Anti-infliximab antibody positive & $9(43)$ \\
Serious adverse events & $2(10)$ \\
\hline
\end{tabular}

\footnotetext{
* Unless otherwise indicated.
}

Serum levels of infliximab and anti-infliximab antibodies. Serum trough infliximab levels were measured using a bridging ELISA. The cutoff value was based on the mean $(+3 \times$ $\mathrm{SD})$ value in serum samples from the 50 negative control sera and this was $0.140 \mu \mathrm{g} / \mathrm{mL}$. Patient serum trough infliximab levels ranged from negative to $58.4 \mu \mathrm{g} / \mathrm{mL}$ (mean $\pm \mathrm{SD}$, $8.6 \pm 10.5)$. Similarly, the assay cutoff point for antiinfliximab-antibody positivity was set at $5 \mathrm{EqU}$, and the patient values ranged from negative to $421,458 \mathrm{EqU}$ (mean \pm SD, $20,845 \pm 74,436 \mathrm{EqU})$. In all, $43 \%(n=9)$ of the patients included in the study tested positive for anti-infliximab antibodies in at least one serum sample. All of the serum samples that tested positive for anti-infliximab antibodies (22/111; $20 \%$ ) also tested negative for infliximab, indicating an inverse relationship between trough serum levels of infliximab and levels of anti-infliximab antibodies. Indeed, the measurements of consecutive serum samples obtained from one patient on different occasions showed a gradual decrease in trough serum levels of infliximab (until negative), which was paralleled by increasing serum levels of anti-infliximab antibodies (Fig. 1A). Taken together, these data suggest that formation of anti-infliximab antibodies accelerates clearance of infliximab from the serum, thereby reducing its efficacy considerably. We also attempted to assess the time course of anti-infliximab antibody development (Fig. 1B). The shortest time between start of therapy and anti-infliximab antibody detection was $112 \mathrm{~d}$, and the longest time without detectable anti-infliximab antibodies was $1734 \mathrm{~d}$. The majority of sera in which antiinfliximab antibodies were detected for the first time (7/9, $78 \%$ ) were taken between 26 and $69 \mathrm{wk}$ from start of therapy.

Two-dimensional electrophoresis of affinity-purified antiinfliximab antibodies. To analyze the different isotypes of the purified anti-infliximab antibodies, we carried out 2D-PAGE of purified anti-infliximab antibodies from a patient who showed a high antibody concentration (Fig. 2). The antibodies
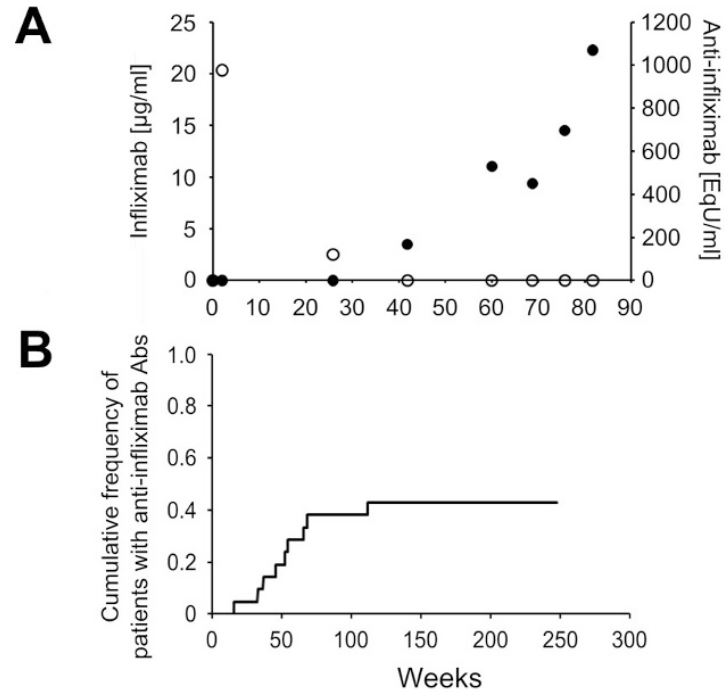

Figure 1. Serum levels of infliximab and anti-infliximab antibodies. $(A)$ Trough serum infliximab levels $(\bigcirc)$ and anti-infliximab-antibody levels $(O)$ from consecutive samples from the same patient over time. $(B)$ Cumulative frequency of duration of therapy before detection of anti-infliximab antibodies. 


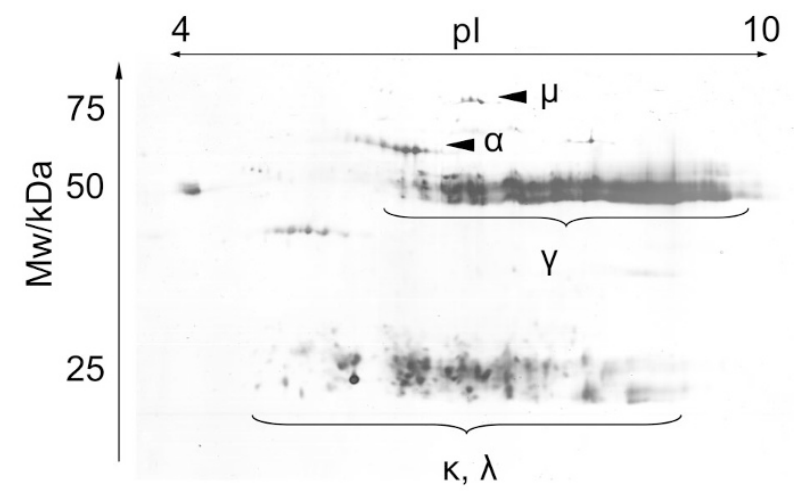

Figure 2. Two-dimensional electrophoresis of affinity-purified antiinfliximab antibodies. $\mu, \operatorname{IgM}$ heavy chain; $\alpha$, IgA heavy chain; $\gamma, \operatorname{IgG}$ heavy chain; $\kappa, \lambda$, IgL light chains (see Methods for details).

were predominantly IgG isotype, although a few spots that corresponded to antibodies of $\operatorname{IgA}$ and $\operatorname{IgM}$ isotypes were seen.

IgG subtype determination of anti-infliximab antibodies. After concluding that the anti-infliximab antibodies were predominantly of the IgG isotype, we determined the IgG subclasses of the affinity purified anti-infliximab antibodies from patients with high concentrations of these antibodies. The majority of the isolated $\mathrm{IgG}$ antibodies were subtypes $\mathrm{IgG} 1$ $(36-65 \%)$ and $\operatorname{IgG} 4(20-55 \%)$, with the $\operatorname{IgG} 2$ and $\operatorname{IgG} 3$ as lesser fractions of the antibodies isolated $(8-11 \%$ and $1-13 \%$, respectively).

Fab neutralization assay. As infliximab is a chimeric MAb with variable domains of murine origin, we would assume that anti-infliximab antibodies will be directed against the amino acid residues of infliximab that are foreign to the human body; i.e. the variable domains. We investigated this by measuring the ability of anti-infliximab antibodies to inhibit (neutralize) binding of infliximab Fab fragment to immobilized TNF. All serum samples that tested positive for anti-infliximab antibodies $(n=22)$ showed neutralizing antibodies, while none of the anti-infliximab-negative sera $(n=89)$ and none of the negative control sera $(n=50)$ showed inhibition of infliximab binding. This alone cannot exclude $a$ priori the possibility that among the polyclonal population of anti-infliximab antibodies there were some that bind to sites other than the variable domains; however, this showed that anti-infliximab-antibody formation is invariably associated with formation of neutralizing antibodies that bind to the variable domains of infliximab and inhibit infliximab binding to TNF.

Epitope mapping. After confirmation that the antiinfliximab antibodies were directed toward the variable domains of infliximab, we wanted to map the epitopes of these antibodies more precisely, using overlapping synthetic peptides that covered the amino acid sequences of both the heavy and light chains of the infliximab variable domains (7). These peptides were synthesized commercially as 15 amino acid residues in length, with successive peptides overlapping by 11 residues. Using a number of complementary approaches, i.e. immobilizing the peptides on nitrocellulose membranes (Fig. $3 A$ ) and in microplate wells (Fig. $3 B$ ) and using the peptides in solution (data not shown), we were not able to show binding

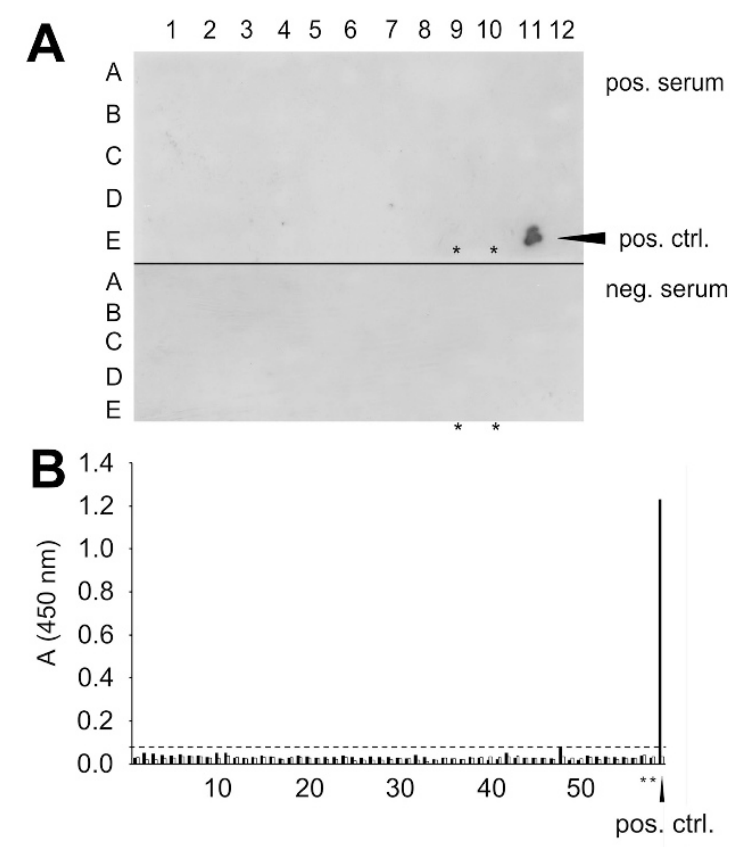

Figure 3. Epitope mapping using overlapping synthetic peptides. (A) Epitope mapping using nitrocellulose-membrane-immobilized peptides. Peptides were spotted onto a nitrocellulose membrane and immunostained with either anti-infliximab-positive serum (upper half) or -negative serum (lower half). (B) Epitope mapping using indirect ELISA. Peptides were immobilized in microplate wells and immunostained with anti-infliximab-positive serum (ם) or -negative serum ( $\square$ ). The cutoff for serum positivity [0.079] (dashed line) was determined as $3 \times$ mean $\mathrm{A}(450 \mathrm{~nm})$ of the signals obtained with negative control sera. *Negative control peptides.

of anti-infliximab antibodies to any of the peptides. We therefore reasoned that the anti-infliximab antibodies bind exclusively to discontinuous epitopes on the surface of infliximab.

Anti-infliximab antibodies bind to infliximab in its native conformation. To confirm that the anti-infliximab antibodies required infliximab in its native conformation for binding, we immobilized serial dilutions of nondenatured and denatured infliximab Fab fragment, and immunostained them with affinity-purified anti-infliximab antibodies. The antibodies bound infliximab Fab fragment with a 32-fold higher affinity when it was in its native, rather that denatured, form (Fig. 4). A faint signal for binding of the antibodies to the denatured form was also seen; however, this was most likely the result of either noncomplete denaturation or refolding of infliximab Fab fragment after immobilization on the membrane.

\section{DISCUSSION}

The use of cytokine-blocking biologics for treatment of connective tissue disorders has proven to be an efficient alternative for patients who are nonresponsive to traditional treatments. Infliximab has been at the forefront of biologic therapies and has shown positive results in both adults and pediatric patients $(14,15)$. The formation of anti-infliximab antibodies has, however, become one of the foremost reasons for drug discontinuation (16). Blocking infliximab binding to its target or accelerating its clearance from serum lead to a loss in efficacy $(17,18)$, while anti-infliximab antibodies also increase the risk of infusion reactions (10). 


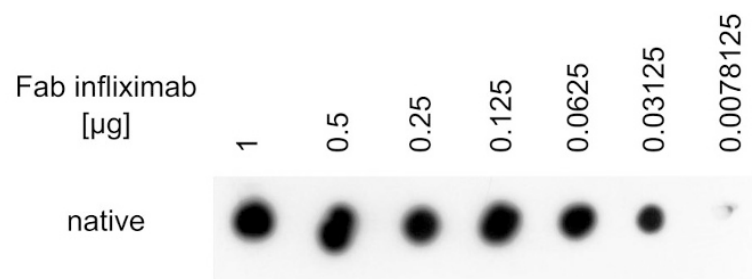

denatured

Figure 4. Anti-infliximab antibodies bind infliximab Fab fragment in its native form, not its denatured form. Serial 2-fold dilutions of infliximab Fab fragment in its native (upper half) and denatured (lower half) forms were immobilized on a nitrocellulose membrane and immunostained with the affinity-purified anti-infliximab antibodies.

The data in this study agree with these concepts. We observed an inverse relationship between trough serum infliximab levels and levels of anti-infliximab antibodies, with none of the sera tested showing concurrent positive levels of both infliximab and anti-infliximab antibodies. The most likely explanation for this is clearance of immune complexes in the liver and spleen (18). We also observed that formation of anti-infliximab antibodies was invariably associated with formation of neutralizing, also called anti-idiotypic, antibodies that block infliximab binding to its target. Taken together, these data explain the decrease in infliximab efficacy seen in patients not responding to treatment. Finckh et al. (19) recently reported that either high anti-infliximab antibody levels or low residual infliximab concentrations was strongly associated with acquired therapeutic resistance to infliximab in adult patients with rheumatoid arthritis; however, this was not the sole reason for loss of efficacy of infliximab. It seems plausible that the same is true for pediatric patients. In turn, several studies have shown that higher doses of infliximab correlate with lower incidence of anti-infliximab-antibody formation and improved infliximab effectiveness both in adults and children $(2,20)$. The monitoring of serum infliximab levels and formation of anti-infliximab antibodies can therefore explain the loss of therapeutic response to infliximab in a number of patients and can help with decisions for future treatments, either by increasing the dose or switching to a different TNF-blocking biologic $(17,21)$.

The exact time course of first appearance of anti-infliximab antibodies are difficult to determine experimentally. Therefore, we can only approximate this from the assay time points. We observed that the majority of samples where antiinfliximab antibodies were detected for the first time were between wk 26 and 69 from start of therapy. In one patient, we detected these antibodies as few as $16 \mathrm{wk}$ from start of therapy. This is very similar to results obtained in the ATTRACT study by St. Clair et al. (22) for adult patients with rheumatoid arthritis: from wk 22 to $54,22-30 \%$ of patients (depending on dosing regimen) had serum infliximab trough levels below the quantifiable limit of the serum infliximab assay. Although they did not measure anti-infliximab antibodies directly, they reasoned that these antibodies were the cause of these results.

To date, there have been very few reports on the nature of anti-infliximab antibodies and their antigenic determinants (epitopes), especially in pediatric patients. Understanding where these anti-infliximab antibodies bind would provide a wealth of information for both researchers and physicians. Most efforts to decrease immunogenicities of therapeutic antibodies have so far been directed at the determination of $\mathrm{T}$ cell epitopes, with the aim of "deimmunization" of the protein drug (23). B-cell epitopes have so far been largely overlooked, most likely due to the associated experimental difficulties. However, deciphering of the actual binding residues would allow much more direct approaches to drug reengineering (24). In this study, we focused on determination of the binding sites of the anti-infliximab antibodies using immunoassays and epitope-mapping techniques. As the variable domains of infliximab are murine in origin, formation of anti-infliximab antibodies that are directed to these regions is not surprising. However, not all amino acid residues are equally immunogenic, and therefore, the elucidation of immunodominant epitopes will provide insight into why anti-infliximab antibodies form only in certain patients treated with infliximab, while in others they do not. We examined this using overlapping 15-mer peptides that covered the entire variable domains of both the heavy and light chains of infliximab. This approach has succeeded in the past, although it is limited to determination of linear epitopes on surfaces of antigen molecules $(25,26)$. We could not, however, reveal any anti-infliximabantibody binding to any of the synthetic peptides under various assay conditions; this indicates that none of these epitopes are linear, i.e. they are all discontinuous. This finding was also confirmed by the significant decrease in binding of the antiinfliximab antibodies to the denatured form of the infliximab Fab fragment.

Most epitope-mapping techniques available today are limited to detection of linear epitopes. The determination of discontinuous epitopes is not as straightforward; hence, this will require much greater investments of time and resources, and ultimately some luck (27). However, mapping of antiinfliximab-antibody epitopes remains a worthwhile pursuit, as this could ultimately lead to an understanding of the reasons governing the immunogenicity of infliximab.

Acknowledgments. We thank Nina Kočevar for help with 2D-PAGE of anti-infliximab antibodies, Chris Berrie for critical review of the manuscript, and last but not least, our colleagues whose insightful comments helped to drive this study.

\section{REFERENCES}

1. Ravelli A, Martini A 2007 Juvenile idiopathic arthritis. Lancet 369:767-778

2. Ruperto N, Lovell DJ, Cuttica R, Wilkinson N, Woo P, Espada G, Wouters C, Silverman ED, Balogh Z, Henrickson M, Apaz M, Baildam E, Fasth A, Gerloni V, Lahdenne P, Prieur A, Ravelli A, Saurenmann RK, Gamir ML, Wulffraat N, Marodi L, Petty RE, Joos R, Zulian F, McCurdy D, Myones BL, Nagy K, Reuman P, Szer I, Travers S, Beutler A, Keenan G, Clark J, Visvanathan S, Fasanmade A, Raychaudhuri A, Mendelsohn A, Martini A, Giannini EH, Organisation PR, Group PR 2007 A randomized, placebo-controlled trial of infliximab plus methotrexate for 
the treatment of polyarticular-course juvenile rheumatoid arthritis. Arthritis Rheum 56:3096-3106

3. Gerloni V, Pontikaki I, Gattinara M, Desiati F, Lupi E, Lurati A, Salmaso A, Fantini F 2005 Efficacy of repeated intravenous infusions of an anti-tumor-necrosis-factoralpha monoclonal antibody, infliximab, in persistently active, refractory juvenile idiopathic arthritis: results of an open-label prospective study. Arthritis Rheum 52:548-553

4. Gartlehner G, Hansen RA, Jonas BL, Thieda P, Lohr KN 2008 Biologics for the treatment of juvenile idiopathic arthritis: a systematic review and critical analysis of the evidence. Clin Rheumatol 27:67-76

5. Lahdenne $P$, Vähäsalo $P$, Honkanen V 2003 Infliximab or etanercept in the treatment of children with refractory juvenile idiopathic arthritis: an open-label study. Ann Rheum Dis 62:245-247

6. Knight DM, Trinh H, Le J, Siegel S, Shealy D, McDonough M, Scallon B, Moore MA, Vilcek J, Daddona P, Ghrayeb J 1993 Construction and initial characterization of a mouse-human chimeric anti-TNF antibody. Mol Immunol 30:1443-1453

7. Le J, Vilcek J, Dadonna P, Ghrayeb J, Knight D, Siegel SA 1997 Methods of treating TNF-alpha-mediated Crohn's disease using chimeric anti-TNF antibodies. US Patent $5,656,272$

8. Gerloni V, Pontikaki I, Gattinara M, Fantini F 2008 Focus on adverse events of tumour necrosis factor alpha blockade in juvenile idiopathic arthritis in an open, monocentric, long-term prospective study of 163 patients. Ann Rheum Dis 67:11451152

9. Koren E, Smith HW, Shores E, Shankar G, Finco-Kent D, Rup B, Barrett Y, Devanarayan V, Gorovits B, Gupta S, Parish T, Quarmby V, Moxness M, Swanson SJ, Taniguchi G, Zuckerman LA, Stebbins CC, Mire-Sluis A 2008 Recommendations on risk-based strategies for detection and characterization of antibodies against biotechnology products. J Immunol Methods 333:1-9

10. Baert F, Noman M, Vermeire S, Van Assche G, D' Haens G, Carbonez A, Rutgeerts P 2003 Influence of immunogenicity on the long-term efficacy of infliximab in Crohn's disease. N Engl J Med 348:601-608

11. Bourdage JS, Lee TN, Taylor JM, Willey MB, Brandt JT, Konrad RJ 2005 Effect of double antigen bridging immunoassay format on antigen coating concentration dependence, and implications for designing immunogenicity assays for monoclonal antibodies. J Pharm Biomed Anal 39:685-690

12. Mortz E, Krogh TN, Vorum H, Görg A 2001 Improved silver-staining protocols for high-sensitivity protein identification using matrix-assisted laser desorption/ ionization time-of-flight analysis. Proteomics 1:1359-1363

13. Kapoor KN, Barry DT, Rees RC, Anthony Dodi I, McArdle SE, Creaser CS, Bonner PL 2009 Estimation of peptide concentration by a modified bicinchoninic acid assay. Anal Biochem 393:138-140

14. Bingham CO 2008 Emerging therapeutics for rheumatoid arthritis. Bull NYU Hosp Jt Dis 66:210-215

15. Haines KA 2007 Juvenile idiopathic arthritis: therapies in the 21st century. Bull NYU Hosp Jt Dis 65:205-211
16. Ruperto N, Lovell DJ, Cuttica R, Woo P, Meiorin S, Wouters C, Silverman ED, Balogh Z, Henrickson M, Davidson J, Foeldvari I, Imundo L, Simonini G, Oppermann J, Xu S, Shen YK, Visvanathan S, Fasanmade A, Mendelsohn A, Martini A, Giannini EH, Paediatric Rheumatology INternational Trials Organization (PRINTO), Pediatric Rheumatology Collaborative Study Group (PRCSG) 2010 Long-term efficacy and safety of infliximab plus methotrexate for the treatment of polyarticular-course juvenile rheumatoid arthritis: findings from an open-label treatment extension. Ann Rheum Dis 69:718-722

17. Aarden L, Ruuls SR, Wolbink G 2008 Immunogenicity of anti-tumor-necrosis-factor antibodies-towards improved methods of anti-antibody measurement. Curr Opin Immunol 20:431-435

18. van der Laken CJ, Voskuyl AE, Roos JC, Stigter van Walsum M, de Groot ER, Wolbink G, Dijkmans BA, Aarden LA 2007 Imaging and serum analysis of immune complex formation of radiolabelled infliximab and anti-infliximab in responders and non-responders to therapy for rheumatoid arthritis. Ann Rheum Dis 66:253-256

19. Finckh A, Dudler J, Wermelinger F, Ciurea A, Kyburz D, Gabay C, Bas S 2010 Influence of anti-infliximab antibodies and residual infliximab concentrations on the occurrence of acquired drug resistance to infliximab in rheumatoid arthritis patients. Joint Bone Spine 77:313-318

20. Maini RN, Breedveld FC, Kalden JR, Smolen JS, Davis D, Macfarlane JD, Antoni C, Leeb B, Elliott MJ, Woody JN, Schaible TF, Feldmann M 1998 Therapeutic efficacy of multiple intravenous infusions of anti-tumor-necrosis-factor-alpha monoclonal antibody combined with low-dose weekly methotrexate in rheumatoid arthritis. Arthritis Rheum 41:1552-1563

21. Dhingra N, Morgan J, Dick AD 2009 Switching biologic agents for uveitis. Eye (Lond) 23:1868-1870

22. St. Clair EW, Wagner CL, Fasanmade AA, Wang B, Schaible T, Kavanaugh A, Keystone EC 2002 The relationship of serum infliximab concentrations to clinical improvement in rheumatoid arthritis: results from ATTRACT, a multicenter, randomized, double-blind, placebo-controlled trial. Arthritis Rheum 46:1451-1459

23. Scott DW, De Groot AS 2010 Can we prevent immunogenicity of human protein drugs? Ann Rheum Dis 69:i72-i76

24. Nagata S, Pastan I 2009 Removal of B-cell epitopes as a practical approach for reducing the immunogenicity of foreign-protein-based therapeutics. Adv Drug Deliv Rev 61:977-985

25. Carter JM, Loomis-Price L 2004 B cell epitope mapping using synthetic peptides. Curr Protoc Immunol Chapter 9: Unit 9.4

26. Heuzenroeder MW, Barton MD, Vanniasinkam T, Phumoonna T 2009 Linear B-cell epitope mapping using enzyme-linked immunosorbent assay for libraries of overlapping synthetic peptides. Methods Mol Biol 524:137-144

27. Irving MB, Craig L, Menendez A, Gangadhar BP, Montero M, van Houten NE, Scott JK 2010 Exploring peptide mimics for the production of antibodies against discontinuous protein epitopes. Mol Immunol 47:1137-1148 